\title{
Ultrasonographic characteristics as a criterion for repeat cytology in benign thyroid nodules
}

\author{
Características ultrassonográficas como critério para \\ repetição da citologia em nódulos tireoidianos benignos
}

Pedro Weslley Rosário', Saulo Purisch²

\begin{abstract}
'Programa de Pós-graduação, Santa Casa de Belo Horizonte, Belo Horizonte, MG, Brasil ${ }^{2}$ Departamento de Tireoide, Serviço de Endocrinologia, Santa Casa de Belo Horizonte, Belo Horizonte, MG, Brasil
\end{abstract}

Correspondence to: Pedro Weslley Rosário Av. Francisco Sales, 1.111, $9^{\circ} \mathrm{D}-$ Santa Efigênia

30150-221 - Belo Horizonte, MG, Brasil

pedrorosario@globo.com

Received on July/30/2009 Accepted on Oct/14/2009

\begin{abstract}
Objective: To report the results of repeat fine-needle aspiration cytology (FNAC) in thyroid nodules with an initial benign cytological diagnosis that grow during follow-up and/or present suspicious ultrasonographic characteristics. Subjects and methods: The sample consisted of 456 patients with 895 nodules. FNAC was repeated after 12 to 18 months in the case of nodules with suspicious ultrasonographic characteristics, irrespective of growth, and when the nodules showed significant growth. Results: Among the 895 nodules examined, 102 (11.4\%) presented suspicious ultrasonographic characteristics. The second FNAC revealed malignancy in 18 $(17.6 \%)$ nodules, including $20 \%(2 / 10)$ of those showing growth and $17.4 \%(16 / 92)$ that did not. Seventy-six (9.6\%) of 793 nodules without suspicious characteristics presented growth. Only one case $(1.3 \%)$ of malignancy was diagnosed by repeat FNAC. Conclusions: The study suggests ultrasonographic characteristics rather than growth as a criterion for repeat FNAC in the case of nodules with an initial benign cytological diagnosis. Arq Bras Endocrinol Metab. 2010;54(1):52-5

Keywords

Thyroid nodule; cytology; ultrasonography; growth
\end{abstract}

\section{RESUMO}

Objetivo: Relatar os resultados da repetição da punção aspirativa com agulha fina (PAAF) em nódulos tireoidianos com diagnóstico citológico inicial benigno que apresentam crescimento durante o acompanhamento e/ou características ultrassonográficas suspeitas. Sujeitos e métodos: A amostra consistiu de 456 pacientes com 895 nódulos. A PAAF foi repetida após 12 a 18 meses nos nódulos com características suspeitas, independente de crescimento, e quando apresentaram crescimento significativo. Resultados: Entre os 895 nódulos avaliados, $102(11,4 \%)$ apresentavam características ultrassonográficas suspeitas. A segunda PAAF revelou malignidade em 18 nódulos $(17,6 \%)$, incluindo $20 \%(2 / 10)$ naqueles com crescimento e $17,4 \%$ (16/92) naqueles sem crescimento. De 793 nódulos sem características suspeitas, $76(9,6 \%)$ apresentaram crescimento. Somente um caso $(1,3 \%)$ de malignidade foi diagnosticado pela repetição da PAAF. Conclusões: 0 estudo sugere características ultrassonográficas mais que crescimento como critério para repetição da PAAF em nódulos com diagnóstico citológico inicial benigno. Arq Bras Endocrinol Metab. 2010;54(1):52-5

\section{Descritores}

Nódulo da tireoide; citologia; ultrassonografia; crescimento

\section{INTRODUCTION}

$\mathrm{F}$ ine-needle aspiration cytology (FNAC) is the best method for the definition of the etiology of thyroid nodules. Although uncommon in ultrasound-guided FNAC, false-negative cases are relevant since a delay in the diagnosis of malignancy may compromise the prognosis of the patient $(1,2)$. For this reason, some investigators recommend repetition of FNAC in the case of nodules with an initial benign cytological diagnosis (3-9). In contrast to this management, it is found the fact that the first diagnosis remains unchanged in most cases $(3,4,6-9)$ and that other patients are unnecessarily 
submitted to surgery because of an unsatisfactory or indeterminate biopsy $(3,5,8,9)$. Thus, knowledge about the characteristics that identify, with a higher probability, nodules harboring malignancy despite benign cytology is important to reduce the number of cases of masked malignancy without exposing a large number of patients to a second procedure. Repetition of FNAC should be restricted to these nodules.

Currently, repeat FNAC is only recommended in cases of benign nodules that show growth during followup (10), but this criterion seems to be poorly sensitive $(4,11)$ and has low positive predictive value for malignancy (12). Additionally, the approach of repeating FNAC was adopted in the case of nodules with suspicious ultrasonographic characteristics despite initial benign cytology even in the absence of size variation. The objective of this study was to report the results of this approach.

\section{SUBJECTS AND METHODS}

All patients who were examined by the author at a private clinic and at Santa Casa de Belo Horizonte between 2003 and 2008, had one or more thyroid nodules and were eligible for this study. Nodules $\leq 1 \mathrm{~cm}$ without suspicious ultrasonographic characteristics and hot nodules on ${ }^{131}$ I scintigraphy performed on patients with low TSH were not submitted to FNAC. The present sample consisted of nodules submitted to FNAC that presented a benign cytological diagnosis (and adequate cellularity). Patients exposed to neck radiation during childhood and adolescence, patients with a family history of medullary or papillary carcinoma (in the latter case, at least two first-degree relatives), and patients with nodule-related symptoms or nodule(s) $\geq 4 \mathrm{~cm}$ were managed differently (submitted to surgery and no repeat FNAC was therefore performed), even in the case of benign cytology, and were excluded from the study. Forty patients who were not reevaluated one year later were excluded. The final sample consisted of 456 patients (362 women, age range 7-88 years, median of 48 years) with 895 nodules. The study was approved by the Research Ethics Committee of Santa Casa de Belo Horizonte.

FNAC was repeated after 12 to 18 months, in the case of nodules with suspicious ultrasonographic characteristics, irrespective of growth, and in the other cases only when the nodule showed significant growth (volume increase $\geq 50 \%$, with at least one of the measurements showing an increase $>20 \%$ and $>2 \mathrm{~mm}$ ) during the same period. The second FNAC and ultrasonography were performed with the same apparatus and by the same examiner who performed the first.

Sonography was performed with a linear multifrequency 10 to $12 \mathrm{MHz}$ transducer for morphological analysis and with a 4.5 to $7 \mathrm{MHz}$ transducer for color Doppler evaluation. The images were analyzed by experienced professionals. Suspicious ultrasonographic characteristics were defined as: microcalcifications; marked hypoechogenicity (when a nodule showed a relatively hypoechoic pattern in regard to the adjacent strap muscle), or two or more findings between hypoechogenicity, microlobulated or irregular margins, predominantly central flow, and taller than wide in shape (being greater in the antero posterior dimension than in the transverse dimension). FNAC was performed with a 22-gauge needle and a 5- or $10-\mathrm{ml}$ syringe and was guided by ultrasonography. The smears were stained with hematoxylin-eosin and analyzed by pathologists experienced in thyroid pathology.

Fisher's exact test or the $\chi^{2}$ test was used to detect differences in the proportion of cases. A p-value $<0.05$ was considered significant.

\section{RESULTS}

Among the 895 nodules $<4 \mathrm{~cm}$ with a benign cytological diagnosis, 102 presented suspicious ultrasonographic characteristics and 76 nodules showed significant growth after 12 to 18 months. FNAC was repeated in 178 nodules. The second FNAC revealed malignancy in 19 nodules, 134 nodules were diagnosed as benign, 12 as indeterminate, and 13 other nodules as inadequate. Histology confirmed the cytological diagnosis in all cases of malignancy.

Table 1 shows the probability of repeat FNAC detecting malignancy in nodules $<4 \mathrm{~cm}$ with an initial benign cytological diagnosis according to the ultrasonographic characteristics and nodule growth.

Table 1. Probability of repeat FNAC detecting malignancy according to ultrasonographic characteristics and nodule growth

\begin{tabular}{lccc}
\hline \multirow{2}{*}{$\begin{array}{l}\text { Suspicious } \\
\text { ultrasonographic } \\
\text { characteristics }\end{array}$} & \multicolumn{2}{c}{$\begin{array}{c}\text { Significant growth after } \\
\text { 12-18 months }\end{array}$} & \\
\cline { 2 - 3 } & Yes & No & \\
\hline Yes & $2 / 10(20 \%)$ & $16 / 92(17.4 \%)$ & $18 / 102(17.6 \%)$ \\
No & $1 / 76(1.3 \%)$ & $717^{\star}$ & $1 / 793(1.2 \%)$ \\
& $3 / 86(3.5 \%)$ & $16 / 809(2 \%)$ & $19 / 895(2.1 \%)$ \\
\hline
\end{tabular}

* FNAC was not repeated in these cases. 


\section{DISCUSSION}

Although presenting a high negative predictive value, benign cytology does not definitively exclude malignancy in thyroid nodules and repetition of FNAC has been proposed for the detection of false-negative cases (3-9). Repetition of FNAC in all cases of nodules with an initial benign cytological diagnosis leads to a final diagnosis of malignancy in only approximately $2 \%$ of cases $(3,4,6-9)$. Due to an indeterminate, suspicious or insufficient cytology result, about $13 \%$ of patients are referred for thyroidectomy exclusively based on the findings of repeat FNAC and most of these patients present benign histology (3,5,7-9). Finally, some investigators defend the need for three cytology exams to ensure the benign character of the nodule $(4,9)$, an approach that increases even further the relevance of the problems cited above.

The detection of masked malignancy without exposing a large number of patients to additional procedures and even to unnecessary surgery is only possible if characteristics are available to identify nodules harboring malignancy with a higher probability, with repeat FNAC being restricted to these cases. Factors that increase the risk of thyroid malignancy, such as exposure to neck radiation during childhood, a family history of medullary or papillary carcinoma and ipsilateral paralysis of the vocal cord, are observed in exceptional cases. With respect to nodule size $\geq 4 \mathrm{~cm}(13,14)$, in addition to doubts about whether this finding is really associated with a false-negative FNAC result $(15,16)$, today it is rarely observed in nodular thyroid disease. On the other hand, the detection of hot nodules by radioiodine scintigraphy, mitigating the possibility of malignancy, requires systematic examination and only few nodules would qualify as "hot". Thus, adoption of these criteria for the repetition of FNAC in the case of benign cytology does not seem to be interesting.

Today, almost all patients with thyroid nodules are submitted to ultrasonography. Although this imaging method alone does not define the etiology of the nodule it assists in the differentiation between benign and malignant nodules $(10,17-20)$. This fact renders ultrasonography a highly attractive tool for the selection of candidates for repeat FNAC in the case of an initial benign cytological diagnosis, but its validation for this purpose is fundamental. Shin and cols. (6) showed that $89 \%$ of nodules in which repeat FNAC revealed malignancy were solid hypoechoic nodules and $56 \%$ presented microcalcifications. In the study of Kwak and cols. (21), who evaluated cases with a benign cytological diagnosis, the malignancy rate was $2.9 \%$ versus $56.6 \%$ in nodules without and with suspicious ultrasonographic characteristics, respectively. Thirty $(96.8 \%)$ of 31 false-negative FNAC results presented suspicious ultrasonographic features (21). Illouz and cols. (9), on defining microcalcifications, lack of a hypoechoic halo and irregular margins as suspicious ultrasonographic characteristics, observed no difference in the frequency of these findings between nodules with persistently benign versus suspicious or malignant cytology in subsequent exams. However, only seven cases of malignancy were detected in that study and surprisingly only $4 \%$ in the second group presented these characteristics (9). In the present study using characteristics of high specificity (17-20), although only $11.4 \%$ of the nodules presented these findings, the chance of malignancy in a second FNAC exam was approximately $17 \%$. Although the FNAC was not repeated in the case of non-suspicious nodules considering this proportion of suspicious nodules, the frequency of malignancy in this group and an overall malignancy rate of approximately $2 \%$ upon repeat FNAC $(3,4,6-9)$ it was concluded that specifically in these cases (non-suspicious nodules) malignancy should be negligible.

The ultrasonographic characteristics were superior as a criterion for repeat FNAC when compared to nodule growth. The same number of patients would be submitted to the exam (11.4\% and 9.6\%), but the frequency of malignancy was higher using the echographic criterion versus the growth criterion ( $17 \%$ versus $3.5 \%)$. In fact, nodule growth is known to have a low positive predictive value for malignancy (12). Considering non-cystic nodules the interval between examinations (12 to 18 months) and an increase in nodule volume $\geq 50 \%$ (growth criterion), the growth rate detected in this investigation $(10 \%)$ was similar to those reported in earlier studies (12,22-25).

This study suggests the use of ultrasonographic findings (hypoechogenicity, microcalcifications, microlobulated or irregular margins, predominantly central flow, taller than wide in shape) rather than nodule growth for the selection of candidate nodules for repeat FNAC despite an initial benign cytological diagnosis.

Acknowledgements: this study was not supported by research funds.

Disclosure: no potential conflict of interest relevant to this article was reported. 


\section{REFERENCES}

1. Yeh MW, Demircan O, Ituarte $\mathrm{P}, \mathrm{Clark} \mathrm{OH}$. False-negative fine-needle aspiration cytology results delay treatment and adversely affect outcome in patients with thyroid carcinoma. Thyroid. 2004;14(3):207-15.

2. Mazzaferri EL, Kloos RT. Clinical review 128: Current approaches to primary therapy for papillary and follicular thyroid cancer. $\mathrm{J}$ Clin Endocrinol Metab. 2001;86(4):1447-63.

3. Chehade JM, Silverberg AB, Kim J, Case C, Mooradian AD. Role of repeated fine-needle aspiration of thyroid nodules with benign cytologic features. Endocr Pract. 2001;7(4):237-43.

4. Orlandi A, Puscar A, Capriata E, Fideleff H. Repeated fine-needle aspiration of the thyroid in benign nodular thyroid disease: critical evaluation of long-term follow-up. Thyroid. 2005;15(3):274-8.

5. Flanagan MB, Ohori NP, Carty SE, Hunt JL. Repeat thyroid nodule fine-needle aspiration in patients with initial benign cytologic results. Am J Clin Pathol. 2006;125(5):698-702.

6. Shin JH, Han BK, Ko K, Choe YH, Oh YL. Value of repeat ultrasound-guided fine-needle aspiration in nodules with benign cytological diagnosis. Acta Radiol. 2006;47(5):469-73.

7. OertelYC, Miyahara-Felipe L, Mendoza MG, Yu K. Value of repeated fine needle aspirations of the thyroid: an analysis of over ten thousand FNAs. Thyroid. 2007;17(11):1061-6.

8. Menéndez-Torre E, Pineda-Arribas J, Martínez-de-Esteban JP, López-Carballo MT, de Miguel C, Salvador P. Value of repeated fine needle aspiration cytology in patients with nodular goiter. Acta Cytol. 2007;51(6):850-2.

9. Illouz F, Rodien P, Saint-André JP, Triau S, Laboureau-Soares S, Dubois $S$, et al. Usefulness of repeated fine-needle cytology in the follow-up of non-operated thyroid nodules. Eur $\mathrm{J}$ Endocrinol. 2007;156(3):303-8.

10. Pacini F, Schlumberger M, Dralle $H$, Elisei $R$, Smit JW, Wiersinga W. European consensus for the management of patients with differentiated thyroid carcinoma of the follicular epithelium. Eur $\mathrm{J}$ Endocrinol. 2006;154(6):787-803.

11. Ito $Y$, Uruno T, Nakano K, Takamura Y, Miya A, Kobayashi K, et al. An observation trial without surgical treatment in patients with papillary microcarcinoma of the thyroid. Thyroid. 2003;13(4):381-7.

12. Alexander EK, Hurwitz S, Heering JP, Benson CB, Frates MC, Doubilet PM, et al. Natural history of benign solid and cystic thyroid nodules. Ann Intern Med. 2003;138(4):315-8.

13. Meko JB, Norton JA. Large cystic/solid thyroid nodules: a potential false-negative fine-needle aspiration. Surgery. 1995;118(6):9961003; discussion 1003-4.
14. McCoy KL, Jabbour N, Ogilvie JB, Ohori NP, Carty SE, Yim JH. The incidence of cancer and rate of false-negative cytology in thyroid nodules greater than or equal to $4 \mathrm{~cm}$ in size. Surgery. 2007;142:837-44; discussion 844.e1-3.

15. Porterfield JR Jr, Grant CS, Dean DS, Thompson GB, Farley DR, Richards ML, et al. Reliability of benign fine needle aspiration cytology of large thyroid nodules. Surgery. 2008;144(6):963-8; discussion 968-9.

16. McHenry CR, Huh ES, Machekano RN. Is nodule size an independent predictor of thyroid malignancy? Surgery. 2008;144(6):10628; discussion 1068-9.

17. Papini E, Guglielmi R, Bianchini A, Crescenzi A, Taccogna S, Nardi $F$, et al. Risk of malignancy in nonpalpable thyroid nodules: predictive value of ultrasound and color-Doppler features. J Clin Endocrinol Metab. 2002;87(5):1941-6.

18. Nóbrega LH, Paiva FJ, Nóbrega ML, Mello LE, Fonseca HA, Costa SO, et al. Predicting malignant involvement in a thyroid nodule: role of ultrasonography. Endocr Pract. 2007;13(3):219-24.

19. Camargo RY, Tomimori EK, Knobel M, Medeiros-Neto G. Preoperative assessment of thyroid nodules: role of ultrasonography and fine needle aspiration biopsy followed by cytology. Clinics (Sao Paulo). 2007;62(4):411-8.

20. Chammas MC, de Araujo-Filho VJ, Moysés RA, Brescia MD, Mulatti GC, Brandão LG, et al. Predictive value for malignancy in the finding of microcalcifications on ultrasonography of thyroid nodules. Head Neck. 2008;30(9):1206-10.

21. Kwak JY, Kim EK, Kim HJ, Kim MJ, Son EJ, Moon HJ. How to combine ultrasound and cytological information in decision making about thyroid nodules. Eur Radiol. 2009;19(8):1923-31.

22. La Rosa GL, Lupo L, Giuffrida D, Gullo D, Vigneri R, Belfiore A. Levothyroxine and potassium iodide are both effective in treating benign solitary solid cold nodules of the thyroid. Ann Intern Med. 1995;122(1):1-8.

23. Erdogan MF, Gursoy A, Erdogan G. Natural course of benign thyroid nodules in a moderately iodine-deficient area. Clin Endocrinol (Oxf). 2006;65(6):767-71.

24. Rago T, Chiovato L, Aghini-Lombardi F, Grasso L, Pinchera A, Vitti P. Non-palpable thyroid nodules in a borderline iodine-sufficient area: detection by ultrasonography and follow-up. J Endocrinol Invest. 2001;24(10):770-6.

25. Quadbeck B, Pruellage J, Roggenbuck U, Hirche H, Janssen OE, Mann K, et al. Long-term follow-up of thyroid nodule growth. Exp Clin Endocrinol Diabetes. 2002;110(7):348-54. 